\title{
The Radiology Characteristic of Pleural Thickening Lesion: Mesothelioma Compared to the Other Pleural Diseases
}

\author{
Karakteristik Gambaran Radiologi Lesi Penebalan Pleura: \\ Mesothelioma dibanding Penyakit Pleura yang Lain
}

\author{
Ana Majdawati \\ Department of Radiology, Faculty of Medicine and Health Science, \\ Universitas Muhammadiyah Yogyakarta
}

DATA NASKAH:

Masuk: 13 Jan 2018

Direviu: 16 Feb 2018

Direvisi: 21 Apr 2018

Diterima: 10 Jun 2018

\section{*KORESPONDENSI:} ana.majdawati@umy.ac.id

DOI:

$10.18196 / \mathrm{mm} .180219$

TIPE ARTIKEL:

Laporan Kasus

\begin{abstract}
Mesothelioma is a malignancy pleural mass characterized by pleural thickening, that difficult to distinguish from other pleural disorders, such as infection, asbestosis, pleural effusion/empyema. This case report is interesting and important because chest $\mathrm{x}$-ray and chest CT have characteristics of pleural abnormalities that can be used as guidelines for the diagnosis of Mesothelioma. A 56 years old woman with cough, chest pain and breathlessness since a few days ago, and it was getting worse. In the chest auscultation, vesicular voices weaken in both lungs. In chest $\mathrm{x}$ ray finding a thin opacity on both hemithorax. The left sinus costophrenicus was blunt. Chest CT finding a pleural thickening in the posterobasal of the chest wall and disseminating to the mediastinum - paraaortic and found an osteodestruction of rib bones. Pleural thickening is circumferensial, lobulated, irregular nodular opasities and calsification. The histopathology is malignant epitheloid cell forms a cohesive nest, glandular structure and a lot of micropapillae in accordance with malignant mesothelioma. Malignant pleural thickening has lesion characteristic of "irregular nodular opacities" on the periphery with or without pleural effuse in chest $\mathrm{x}$ ray and in chest CT shows the form of lesions are circumferential, lobulated, encase lung parenchyma.
\end{abstract}

Keywords: Pleural Thickening; Characteristic of Lesions; Chest X Ray; Chest CT Scan; Mesothelioma

Abstrak: Mesothelioma adalah massa pleura maligna yang ditandai oleh penebalan pleura. Penebalan pleura ini sulit dibedakan dengan penyakit yang menyebabkan penebalan pleura lainnya, seperti yang disebabkan infeksi, asbestosis, efusi pleura / empiema. Laporan kasus ini menarik dan penting karena hasil radiografi toraks dan CT scan toraks menunjukkan karakteristik lesi yang sesuai dengan Mesothelioma dan dapat dibedakan dengan karakteristik lesi penebalan pleura pada kasus dengan penyebab yang lain. Dilaporkan seorang wanita 56 tahun dengan keluhan batuk, nyeri dada dan sesak napas sejak beberapa hari yang lalu, dan semakin parah. Auskultasi dada terdengar suara vesikular melemah di kedua paru, terutama di basal paru. Radiografi toraks tampak opasitas tipis pada kedua hemitoraks, sinus costophrenicus kiri tumpul. Hasil CT scan toraks, terdapat penebalan pleura di posterobasal dinding dada dan menyebar ke mediastinum termasuk paraaortic. Tampak osteodestruksi costa 7.8 kiri posterolateral. Penebalan pleura bersifat circumferensial, lobulated, opasitas nodular irreguler, kalsifikasi (+). Hasil pemeriksaan histopatologi ditemukan sel epiteloid ganas membentuk sarang kohesif, struktur kelenjar dan banyak mikropapilla sesuai dengan mesothelioma ganas. Radiografi toraks menunjukkan penebalan pleura ganas memiliki karakteristik lesi 
"opasitas nodular irregular" pada dinding dada dengan atau tanpa efusi pleura. Karakteristik mesothelioma pada CT scan dada menunjukkan lesi dapat bersifat circumferensial, lobulated dan melingkupi paru.

Kata kunci: Penebalan Pleura; Karakteristik Lesi; Radiografi Toraks; CT Scan Toraks; Mesothelioma

\section{INTRODUCTION}

The case of Mesothelioma is a case that is quite common in mining or industrial environments and the most common age is 40-50 years with a peak age of 70 years. In the United States the incidence of mesothelioma cases is found in many men compared to women with an incidence of 15 cases per million. Diagnosis of mesothelioma is not easy, because the course of the disease is long so that the characteristics of radiological lesions both plain radiographs and $\mathrm{CT}$ thoracic scans are very important to diagnose this case early. ${ }^{1,2}$

The mesothelioma is a mass of malignant in pleural, characterized by the pleural thickening that is radiologically difficult to be distinguished from other pleural diseases. The thickening of pleural can be focal and diffuse which is malignant or benign depending on the cause. The mesothelioma is diffuse thickening of the pleural which dissemina-ting in the hemithorax and is malignant and unilateral. ${ }^{1,3}$ The differential diagnosis of mesothelioma is a thickening of the diffuse benign pleural caused by infection, namely empyema and tuberculosis. In the chest $x$ ray, pleural is non-visualized organ and it becomes visualized when there is thickening. The presence of pleural thickening is commonly in parietal pleural or visceral pleural which can be benign or malignant, and it can be classified based on its morphology, i.e. focal, diffuse and nodular. Mesothelioma is a malignant mass in pleural which is the thin tissue lining that covering the lung, chest wall, cardiac and testis. ${ }^{3,4}$ This case is interesting and important because it has a chest $x$ ray and Chest $C T$ finding are clear for mesothelioma cases. This case report aims to determine the characteristics of radiological lesions based on chest $x$ ray and chest $C T$ Scan on pleural thickening according to the cause and type of lesion which disseminating. Therefore the diagnostic and placement of pleural thickening can be executed immediately to reduce the complications and decrease the morbidity and mortality rates.

\section{CASE REPORT}

A 56 years old woman with some complaint were cough, chest pain and breathlessness. The patient living near to the asbestos factory and her husband worked there. The patient felt the complaint since a few days ago, and it was getting worse. The patient looked weak and thin, was suffering breathless and chest retraction. In the chest auscultation, vesicular voices weaken in both lungs, especially in the basal. Furthermore, the cardiac, abdomen and system of extremities were normal. In chest $x$ ray, it could be seen a thin opacity on both hemithorax. The bronchovascular marking in both lungs was faint/blurred, especially the right side. The sinus costophrenicus of the left lung was blunt, and the bilateral pleural thickening existed in the second side of the hemithorax in laterobasal aspect. Moreover, it was found an osteodestruction of rib bones 7.8 left posterolateral. The mediastinum was in the middle, and the size of cardiac was normal (Figure 1. and Figure 2.).

In chest CT scan, there was pleural thickening in the posterobasal of the chest wall and disseminating to the mediastinum-paraaortic (Figure 2.)

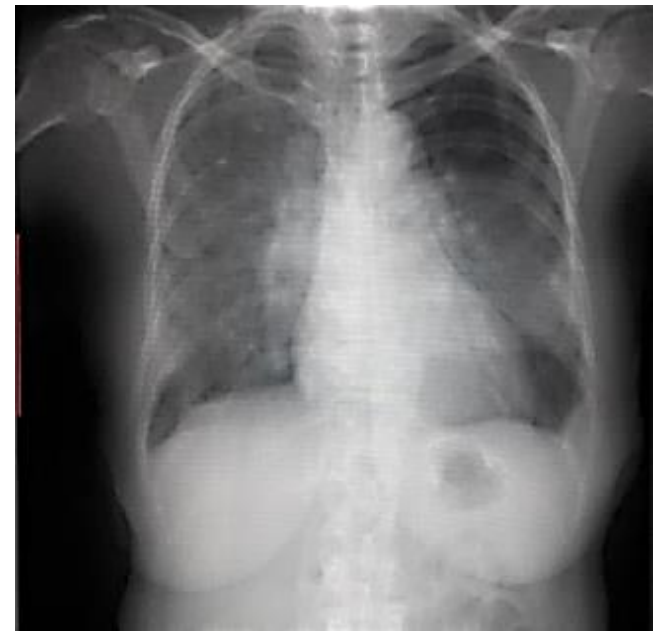

Figure 1. The Chest X Ray of Lungs Condition: There Was A Faint Opacity in Both Lungs, Sinus Costo-phrenicus of Left Lung was Blunt and the Pleural Thickening Existed

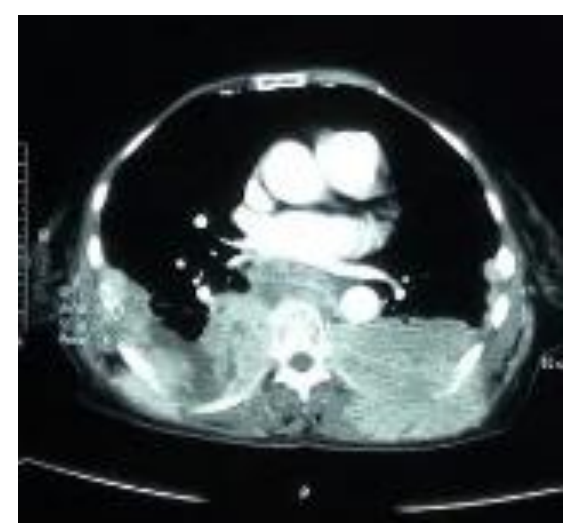

Figure 2. Axial CT Scan of Thorax, Soft Tissue Window 
In the axial chest CT scan, there was isodense lesions on the lobulated, classification (+) in posteromedial bilateral chest wall, especially in the left side, which disseminating and infiltrating the rib bones to the posterior and affecting the muscles around the thoracic vertebral bone ( $\mathrm{m}$. erector spinae), right posterolateral infiltration of the rib bone to the outside of the chest wall.

The isodense lesions were disseminating from the anterior to the mediastinum (retrocardial) and peri-aorta descendens. It can be seen the osteodestruction rib bone 7,8 right and left posterior aspects.

Sagittal chest CT scan shows the inhomogeneous isodense with the irregular surface, and the classification (+) is wider to the direction of the posterior infiltration bone system of thoracic vertebrae.
The thoracic vertebrae bone shows minimum osteodestruction.

Coronal chest CT Scan shows isodense lesions in the form of amorphous, irregular edge is getting wider in chest wall posteromedial aspect. The lesion is getting wider up to medial to the direction of thoracic per vertebrate. The conclusion of chest CT Scan: the lesion leads to mesothelioma (pleural mass tend to be malignant) with osteodestruction of costa dan corpus of thoracic vertertebrae 7-10.

Lesions sampling is conducted by using guiding of chest CT scan. Then, the preparation and the examination of histopathology is conducted. The results are malignant epitheloid cell forms a cohesive nest, glandular structure and a lot of micropapillae in accordance with malignant mesothelioma (Epitheloid Mesothelioma).

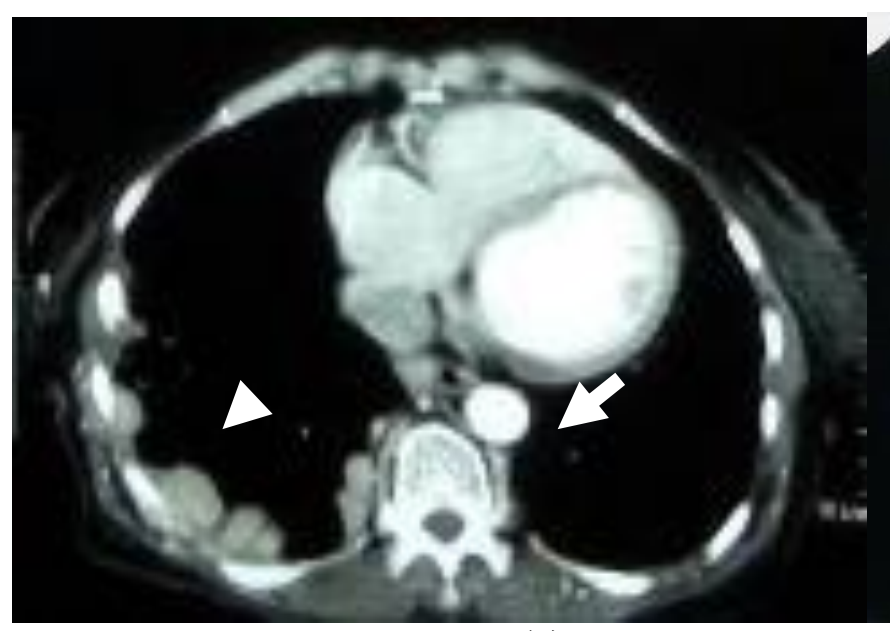

(a)

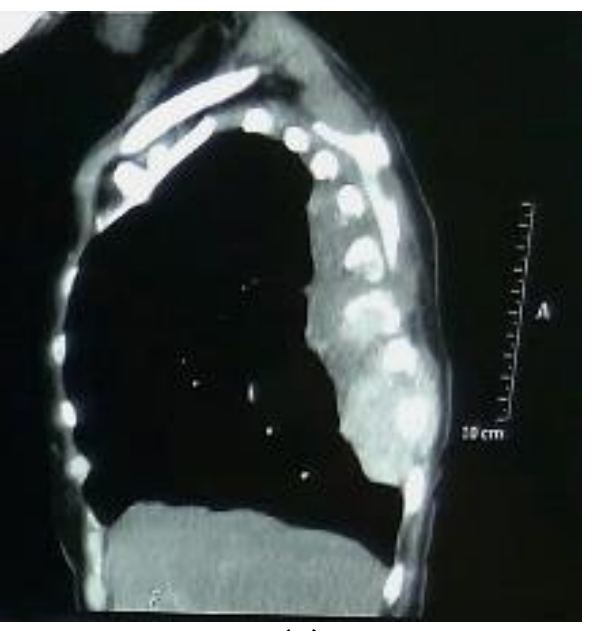

(b)

Figure 3. a) Axial CT scan, Nodular pleural thickening (white arrow), b) Sagittal chest CT scan of the soft tissue. It can be seen the irregular in the diaphragm (white arrow)

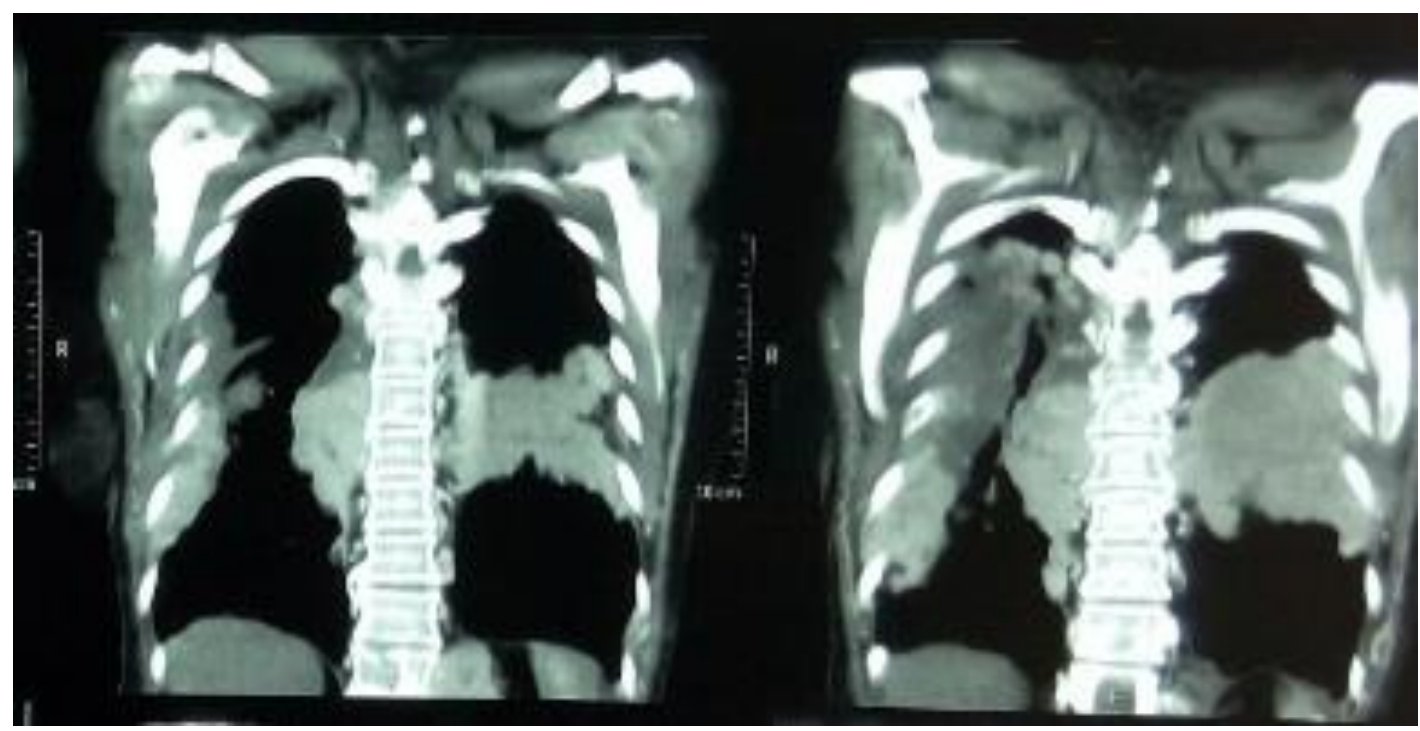

Figure 4. Coronal chest CT scan with soft tissue condition 


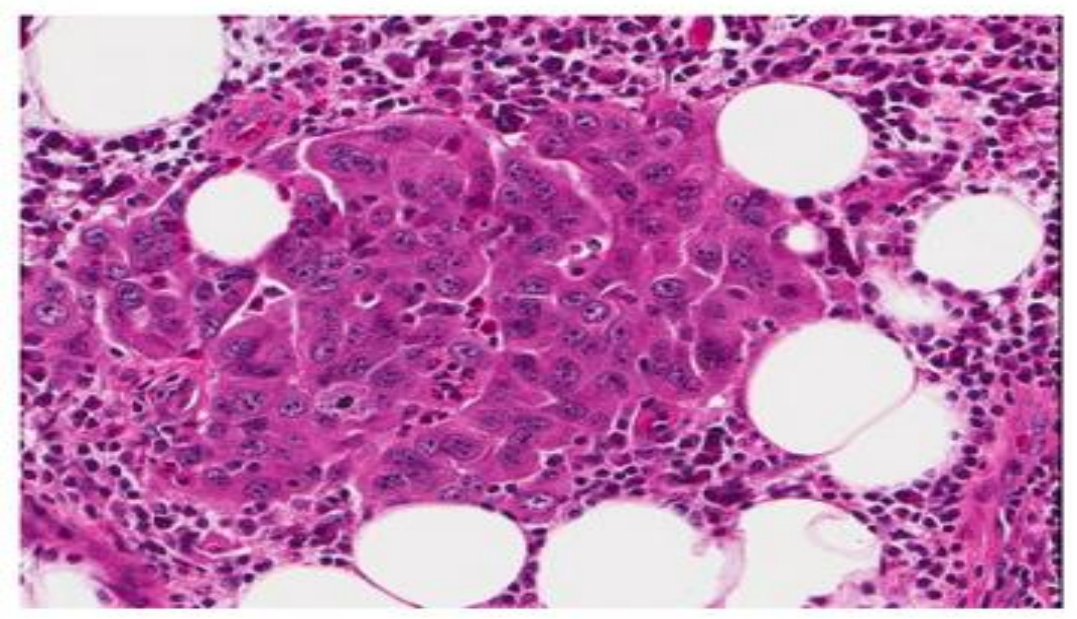

Figure 5. Histopathology (Hematoxylin-eosin, 200x) : Malignant Epithelial Cells Forms A Cohesive Nest, Glandular Structure and A Lot of Micropapillae in Accordance with Malignant Mesothelioma (Epitheloid Mesothelioma)

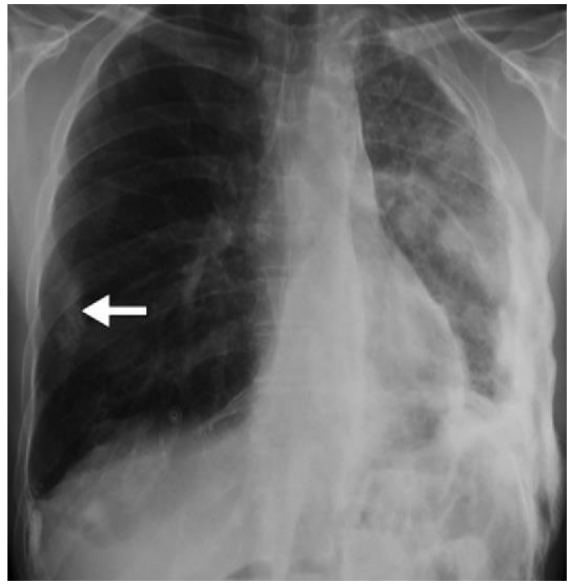

a)

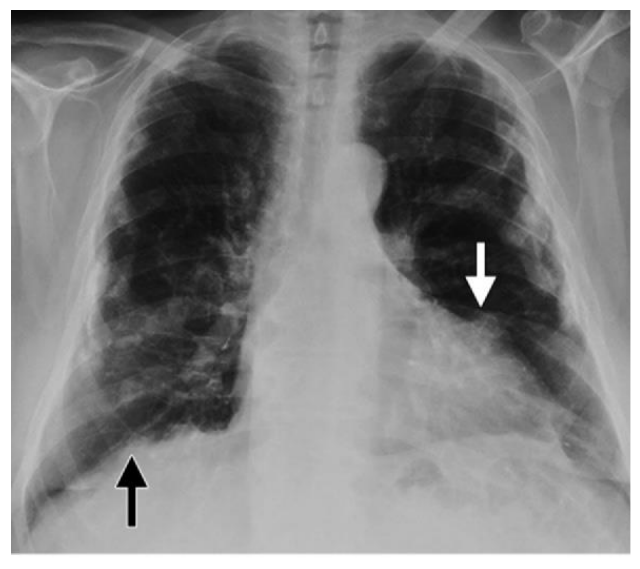

b)

Figure 6. a) Nodular Pleural Thickening (White Arrow). b) Pericardial, Pleural Thickening, A "Shaggy" Cardiac Silhouette (White Arrow) and Diaphragm Irregularity "Ill-Defined Diaphragmatic Contours" (Black Arrow) (Radio Graphics 2014; 34:1692-1706)

\section{DISCUSSION}

How are the characteristic of the description of radiology in the chest $x$ ray and $C T$ scan in the mesothelioma compared to other pleural disorders (tuberculosis and fungal infections)? Several pleura disorders in the chest $x$ ray have some benign or malignant characteristics and are caused by infection or not. The pleura lesion characteristics in the chest $x$ ray are based on their causes. Those are malignant mesothelioma signed by the irregular nodular picture which is seen in the chest wall periphery part with or without pleural effusion. Pleural effusion in the mesothelioma is usually unilateral, the thickening of pleura is massive and getting wider through the fissure interlobar. $., 5,6$
Mesothelioma encases the lung surface (lung encasement) causing the lung's volume decreases "loss of lung volume", diaphragm elevation, mediastinum and retraction of hemithorax and spatial intercostal in the lesion area. Pleural thickening is in the form of nodular (nodular pleural thickening), circumferential and pleural wall thickening is more than $1 \mathrm{~cm}$. Pericardial, pleural thickening looked irregular is called by a "shaggy" cardiac silhouette, and the surface of the diaphragm which is looked irregular and non-slippery edges is called by "ill-defined diaphragmatic contours". Pleural thickening in mesothelioma is sometimes accompanied by plaque /classification which looks lined up. The location of the pleural thickening in mesothelioma usually is in the part of lung basal or medio basal hemi- 
thorax. $3,6,7,8,9,10$

Chest CT scan in the mesothelioma shows more clearly than chest $x$ ray. Pleural thickening as well as pleural effusion and pleural classification as well as lymphonodi around hillus or mediastinum look more clearly and can be differentiated. The spread of lesion in the mesothelioma both intrathoracic and extrathoracic, and bone and soft tissue involvement around the lesion can be better assessed. ${ }^{3,8}$ Chest CT scan can assess the mesothelioma in more detail, pleura thickening circumferential (sensitivity $41 \%$, specificity $100 \%$ ), parietal pleural thickening $>1 \mathrm{~cm}$ (sensitivity $36 \%$, specificity $94 \%$ ), nodularity (sensitivity 51\%, specificity $94 \%$ ) and the involvement of mediastinum pleural (sensitivity $56 \%$, specificity $88 \%) .^{3}$

Diffuse pleural thickening which is benign is caused by asbestosis, the side effect of radiotherapy and infections (the most frequent is tuberculosis and empyema). Asbestos is a particle which is very small (it's different from the dust particle in general). It can go through lung filtration system and enter the lungs, embedded in the pleura and another area such as interstitium. Thus, it causes inflammation and the formation of pleural plaque or "scarring". Pleural thickening in tuberculosis usually occur in the lungs apex and accompanied by fibrosis tissue in the pulmonary parenchyma. The classification is usually in the thickening pleura, and it can happen in the pulmonary parenchyma in the form of calcification nodules. $5,6,7,8,9,10$

\section{CONCLUSION}

Pleural thickening leading to a malignant and benign lesion on chest $x$ ray and $C T$ scan has a different characteristic. Malignant mesothelioma (malignant pleural thickening) has lesion characteristic of "irregular nodular opacities" that can be seen on the periphery with or without pleural effuse. The characteristic of mesothelioma on the chest CT scan shows the lesion in the form of circumferential, lobulated, encase lung parenchyma. The soft tissue mass often occurs on the interlobar fissure of pleural classification, especially on the thoracic wall of the basal aspect.

Pleural thickening which leads to benign has the characteristic that depends on its causes. Pleural thickening caused by the infiltration of asbestos in the lungs and pleura has a description as a scar on the hemithorax wall with its specific location can be anywhere on this wall. Asbestosis is the classification of bilateral pleura and diffuse pleural thickening. Pleural thickening caused by the infection of tuberculosis has a characteristic of fibrosis tissue with classification and location usually are in the lungs apex. This benign pleural thickening usually involves the lesion in the pulmonary parenchyma accompanied by consolidation with fibroinfiltrate and calcification.

\section{ETHICAL CONSIDERATION}

Tha chest $\mathrm{CT}$ scan examination has received approval from the patient and his family

\section{CONTRIBUTORS}

Radiographers of RS PKU Muhammadiyah Gamping, Yogyakarta contributed to data collection. I contributed to analysis of the case and revision of manuscript and approved the final manuscript.

\section{REFERENCES}

1. Luciano C, Francesco A, Dario G, Nicola S, Edoardo $\mathrm{P}$ and Andrea V. Diagnostic imaging and workup of malignant pleural mesothelioma. Acta Biomed 2017; Vol. 88, N. 2: 134-142 DOI: 10.23750

2. Frank EM. Mesothelioma: A Review. Ochsner I. 2012 Spring; 12(1): 70-79.

3. Downer NJ, Ali NJ, Au-Yong ITH. Investigating Pleural Thickening. BMJ, 2013; 346 (jan03 1): e8376-e8376.

4. Wang ZJ, Reddy GP, Gotway MB, Higgins CB, Jablons DM, Ramaswamy M, et al. Malignant Pleural Mesothelioma: Evaluation with CT, MR Imaging, and PET. RadioGraphics 2004; 24:105119

5. Alfudhili KM, Lynch DA, Laurent F, Ferretti GR, Dunet V, Beigelman-Aubry C. Focal Pleural Thickening Mimicking Pleural Plaques on Chest Computed Tomography: Tips and Tricks. Br J Radiol, 2016; 89 (1057): 20150792.

6. Nickell LT, Lichtenberger JP, Khorashadi L, Abbott GF, Carter BW. Multimodality Imaging for Characterization, Classification and Staging of Malignant Pleural Mesothelioma. RadioGraphics, 2014; 34 (6): 1692-706.

7. Aziz F. Radiological Findings in a Case of Advance Staged Mesothelioma. J Thorac Dis, 2009; 1 (1): 46-7.

8. Great Britain, Department for Work and Pensions. Diffuse pleural thickening. 2016. at: https://www.gov.uk/government/ publications/diffuse-pleural-thickening-iiac-report.

9. Kim YK, Kim JS, Lee KW, Yi CA, Koo JM, Jung SH. Multidetector CT Findings and Differential Diagnoses of Malignant Pleural Mesothelioma and Metastatic Pleural Diseases in Korea. Korean J Radiol 2016;17(4):545-553 
10. Ilsen B, Vandenbroucke F, -Aubry CB, Brussaard $\mathrm{C}$ and Mey JD. Review Article Comparative Interpretation of CT and Standard Radiography of the Pleura. Journal of the Belgian Society of Radiology, 100(1): 106, pp. 1-10, DOI: http://dx.doi.org/10.5334/jbr-btr.1229 